\title{
"Permeating all community activities"?; comparing events and programming in Westminster and Tower Hamlets public libraries
}

\author{
Meredith Ship, Lyn Robinson
}

\begin{abstract}
A comparative study of events and programming in two London public library services, Westminster and Tower Hamlets, is reported. The two services offer the same proportion of 'engagement' programming. Tower Hamlets operates a novel service model, though one with long antecedents, integrating library, learning and cultural services. Its extensive programmes of educational and special events have led to a great increase in visitors, though not to a corresponding increase in use of core library services.
\end{abstract}

\section{Introduction}

This study considers two current approaches to the changes and challenges facing English public libraries: the rebranding of a library service as a set of Ideas Stores; and the promotion of 'engagement' events and activities additional to the traditional library mission. This is done by the comparison of library services in two inner London boroughs; one with a rebranded and restructured service, and one continuing with the more familiar model. Comparisons cover the provision of traditional core services, as well as more unusual ones, aimed at active engagement with the community.

\section{Literature review}

Well before the controversial closures and restructurings due to financial pressures of 2010-11, the English public library service found it necessary to reconsider its place, in a changing social, economic and technical context. This led to debates on fundamental issues relating to its purpose, role and activities; see

\section{Authors}

Meredith Ship graduated from City University London in 2010 with a Master's of Science in Library Science. She is currently a Student Advisor at Keuka College in Penn Yan, New York.

Lyn Robinson is Programme Director for library and information science at the Department of Information Science, City University London.

Email:1yn@soi.city.ac.uk 
for example, Black (1996), Usherwood (2007), McMenemy (2009) and Pateman and Vincent (2010).

Two significant responses to this changing environment have included: rebranding, as Idea Stores [Tower Hamlets], Discovery Centres [Winchester], iKnow [Gateshead], REAL [Glasgow] and others (Hood and Henderson 2005). Often, but not always associated with such a rebranding is an emphasis on new kinds of services, beyond the familiar provision of documents, information, and reading/study spaces (Clarke, 2007; Begg, 2009; Pitman, 2012).

It should be noted that, although a 'community hub', as such rebrandings have often been termed, may seem a very modern concept, this image for the public library is, in fact, quite long-standing. Murison $(1988,126)$ wrote of post-1974 UK library development with the:

realization that the library is not limited in its work to its own building, to its stock or to its staff. Because it is a social institution which will affect people's whole lives it is imperative that it should permeate all community activities.

(Murison, 1988, 126)

In earlier years, Eric Leyland, librarian of the East London borough of Chingford, envisaged community cultural centres with public libraries as their nuclei (Leyland, 1938; Kelly, 1973), while Edward Sydney, librarian of another East London borough, Leyton, between 1934 and 1950:

declared that the library should be 'the headquarters of all local cultural activities', and should be equipped for this purpose.

(Kelly, 1973, 307)

They may also act as "one of the fundamental instruments in the continuous education and development of the adult citizen" (McMenemy, 2000, 20).

The definitions of "traditional" and "engagement" are taken from those used in the influential modernisation review of the English public library service (DCMS, 2010). Here, the "core offer" includes:

free access to a range and quality of book stock to browse and borrow and online resources and information that meet local needs (including e-books as the market grows).

(DCMS, 2010)

This is supported by provisions for physical and online access and use. A "local offer", to be geared to local needs, includes provision for learning, an events programme, programmes of engagement with the community, and provisions of space for various community use.

We use the term 'traditional' in this paper following usage in the DCMS report, which notes that "libraries' traditional role has been providing books, learning and information" (DCMS, 2010, 38). Similarly, the term "engagement" is used with the same meaning as in the report: 
as every good librarian knows, public libraries are not about sitting back and passively waiting for people to borrow your books - they are about active engagement with the community.

(DCMS, 2010, 3)

For the purpose of this study, 'engagement' programming is understood as the use of the library space for events other than those centred on books, reading, and information provision. This categorisation covers a very wide variety of education, cultural and recreational events, and is aimed to capture the extent to which the library is operating away from strictly collection-based activity. While the best way of distinguishing between these two forms of library activity, and the best names for them, may be debated, the approach taken here, based on the definitions of the modernisation review, certainly allows insight into the issues.

Programming of this sort, although it is sometimes regarded as a novel idea, has a long history in the UK public library; as Begg $(2009,631)$ points out, "library buildings have always included space for non-book activities and materials". Kelly (1973) and Ship (2010) give numerous early examples, from wildflower stands at Bromley, to a movie club at Leytonstone and theatrical performances at Swindon. Sydney (1950), referred to above, describes extensive programmes of this kind, both of a cultural and an educational nature, in the UK service of 60 years ago. Surveys carried out in 1964 (Joliffe, 1968) and in 1970 (Whatley, 1972) show the diversity of innovative programming in UK public libraries at that time, usually under the heading of 'library extension activities'; from pet workshops at St Helens, to flower shows at Lambeth and concerts at Hackney.

The extent to which the public library should be involved in such programming has been a matter for debate. McMenemy (2009), for example, reminds us that lifelong learning - which not need be directly associated with books or library services - is a continuous strand in the development of the public library service, while the IFLA Public Library Service Guidelines recommend that:

wherever possible the library should also be available for community use, for example, for meetings and exhibitions and in larger buildings for theatrical, musical, audiovisual and media performances.

(Koontz and Gubbin, 2010, 15)

Such programming has been shown to be of value for particular groups, such as female patrons (Cassell and Weibel, 2007) and recent immigrants (Varheim, 2011). Other commentators, such as Usherwood (2007), while defending the role of the public library in promoting cultural events, are concerned that this may mean an undesirable move away from core mission, essentially to do with books and information. This study aims to examine these issues, albeit on a small scale.

\section{Study background and objectives}

The library services of the inner London boroughs of Tower Hamlets and Westminster were chosen for the evaluation, as an example of a service which has undergone a well-publicised rebranding and restructuring, and an example of a comparable service which offered a well-known and well-respected library provision without having undergone restructuring. Although the two boroughs 
have different socio-economic profiles, and have traditionally been controlled by local governments of differing political views, the commonality in situation (inner London), size (area 7.6 and 8.3 square miles respectively), population (252,000 and 221,000 respectively), and financial resources makes for a realistic comparison. Full comparative data for the boroughs are provided by the Greater London Authority (GLA, 2011).

The study set out to:

- compare the programmes of events offered by the two services;

- assess whether there was a link between the programme and use of the library service in general;

- assess whether this was associated with the service model and branding.

\section{Methodology}

Four methods were used for the study:

- examination of mission statements, or similar documents;

- examination of programming and take-up;

- examination of conventional library functions;

- obtaining librarians' views.

Full details of the survey and results are available in the Masters dissertation on which this paper is based (Ship, 2010). Ethical issues were assessed against the City University research ethics checklist. No ethical problems were identified; interviewees were fully informed as to the purpose of the research, and all interview responses were anonymised.

This methodology imposed some limitations on the results to be expected. Although the choice of two inner London services means that like is being compared with like, with some caveats noted below, it does mean that the results cannot necessarily be extrapolated to the rest of the country. The examination of only two services also limits the generalisabilty of the results, and correlations found between the nature of the service and the events provided do not necessarily imply causation. The nature of the study - essentially a 'snapshot' of the activities of the two services over one calendar year - did not allow for a study of development and changes over time, although this was emerged to some extent in views of the service providers. However, allowing for these points, the study method should be able to show if there are clear inter-relations between the factors.

\section{Results}

The results are described here under four headings: mission statements; programming; library services; and librarian viewpoint. 


\subsection{Mission statements}

A direct comparison was not possible, since the Westminster service does not have a public formally stated mission statement.

Tower Hamlets, by contrast, has a detailed mission statement for its libraries, set out initially in a report aimed at revitalising the service (Tower Hamlets, 1999), which launched the, at the time controversial, restructuring and rebranding of the service, most notably signified by its striking new Idea Store buildings (Wills, 2003). This specified, inter alia, that:

"The Idea Stores will be the first place that people will go to for information about any aspect of their lives and to gain new skills. They will offer library and lifelong learning facilities in an integrated and attractive way."

"The Idea Stores will also be located in a different way - at the heart of our neighbourhood shopping centres, near or beside supermarkets wherever possible."

"The primary objective of Idea Stores will be to empower individuals to help themselves, whether it be learning to read, pursuing hobbies, becoming more employable, learning about healthy living or seeking a job."

"Just as importantly, they will also be places where people go to have fun, participate in cultural activities, meet friends and relax. Idea is about the whole person. As much emphasis will be placed on bringing the community together in a stimulating environment as on information and learning."

"The Idea Store network has been deliberately planned to maximise use. ...This ambitious plan has two simple but ambitious targets. It is conservatively estimated that the completed network will double the number of visits to libraries to approximately $2 m$ visits per year. It is conservatively estimated that it will double the number of people engaged in lifelong learning to a minimum of 12000 ."

After ten years, Tower Hamlets updated the Idea Store strategy and mission statement. Whereas the original mission of the Idea Store was to create an integrated library, learning, entertainment and information hub, the revised mission sets out to improve the Idea Store service model by strengthening core library services, as well as by focussing more explicitly on the goal of becoming library, learning, and information resource centres for employability and healthy living (Tower Hamlets, 2009).

The development and updating of the Idea Store mission statements is an indication of a commitment to refresh the public library service in order to ensure that its libraries meet the evolving needs of borough residents, and in particular to ensure the integration of functions and services.

The fact that the Westminster public library service lacks a mission statement does not imply a lack of direction, still less a weak service offer; this service is rightly regarded as one of the strongest library services in inner London. Lack of such an explicit statement may, however, limit the potential for developing and extending services beyond current provision. 


\subsection{Programming}

The original intention was to compare all events and programming in the two services over the same calendar year period. Inconsistencies in the data available meant that this was not feasible, and the study compared two slightly different time periods, for which the most complete data were available for each service; full details are given in Ship (2010).

Westminster maintains an archive of library events, but this is deliberately selective and representative, rather than complete. Furthermore, although the nature of the events is usually clear, some are categorised by uninformative designators, such as EVENT or OTHER. The archive is structured by financial year, and therefore data were taken from the most recent period available, April 2009 to March 2010. Archive data was augmented by details of additional events provided by each of the borough's libraries, and particular attention focused on the 'regular events' being offered in June 2010. The number of participants at events is recorded, though not always completely or consistently.

Tower Hamlets does not maintain any archive of library events; systematic recording began only recently, and is also incomplete. Information on lifelong learning events in libraries is recorded separately, and structured by academic year. Data from these two sources were therefore combined for the most recent period available, September 2009 to August 2010; again, 'regular events' advertised in June 2010 were enumerated completely. During the period of study, attendance at events was not recorded systematically.

Despite the somewhat incomplete and inconsistent nature of the available data, it was possible to produce an informative comparison of the events in the two services, since the data point to consistent trends, similarities and distinctions.

The numbers of events, and of participants, are substantial. The Westminster archive, noted above as incomplete, records 8,149 library events in 2008/09, which were attended by 174,081 people and in 2009/10, 11,500 events and programmes, attended by 227,463 people.

Both services offer a range of 'traditional' library and book-related events, such as reading groups, writing classes, homework clubs, and children's storytelling events, and both participate in nationally organised events such as Summer Reading Challenge, Black History Month and National Health Awareness campaigns. Apart from educational courses, noted below, both also offer innovative engagement events, such as musical and theatrical performances, Jobseeker support, and ICT training.

A difference between the two services is the extent to which lifelong learning courses and events took place in libraries. Westminster has extensive adult education with several hundred courses offered, but only a very small number were based in libraries, with little evident formal interaction or synergy between library and education provision. By contrast, of the similar number of courses offered in Tower Hamlets, nearly a third (288/800) were provided in one of the four Idea Stores. 
A comparison of the situation in the two services can be made by distinguishing their provision as engagement and traditional, and free or fee-paying. The percentages quoted in Tables 1, 2, 3 and 4 should not be regarded as exact, since there is some extrapolation to allow for incomplete data, and the boundaries between traditional and engagement events are not clearly fixed, but the general picture emerges clearly.

\begin{tabular}{|l|l|l|l|l|l|}
\hline & $\begin{array}{l}\text { Traditional } \\
\text { and free }\end{array}$ & $\begin{array}{l}\text { Engagement } \\
\text { and free }\end{array}$ & $\begin{array}{l}\text { Traditional } \\
\text { and fee-based }\end{array}$ & $\begin{array}{l}\text { Engagement } \\
\text { and fee-based }\end{array}$ & $\begin{array}{l}\text { Total } \\
\text { Events }\end{array}$ \\
\hline $\begin{array}{l}\text { Special } \\
\text { Events/ } \\
\text { year }\end{array}$ & $30 \%$ & $69 \%$ & $0 \%$ & $1 \%$ & $108 / \mathrm{yr}$ \\
\hline $\begin{array}{l}\text { Regular } \\
\text { Events/ } \\
\text { month }\end{array}$ & $38 \%$ & $60 \%$ & $0 \%$ & $2 \%$ & $95 / \mathrm{mo}$ \\
\hline
\end{tabular}

Table 1: Westminster Special and Regular Library Events

\begin{tabular}{|l|l|l|}
\hline & Traditional (Free \& Fee-based) & $\begin{array}{l}\text { Engagement (Free \& Fee- } \\
\text { based) }\end{array}$ \\
\hline Special Events/year & $30 \%$ & $70 \%$ \\
\hline Regular Events/month & $38 \%$ & $62 \%$ \\
\hline Total Events/year & $37 \%$ & $63 \%$ \\
\hline
\end{tabular}

Table 2: Traditional vs. Engagement Events (Westminster)

\begin{tabular}{|l|l|l|l|l|l|}
\hline & $\begin{array}{l}\text { Traditional } \\
\text { and free }\end{array}$ & $\begin{array}{l}\text { Engagement } \\
\text { and free }\end{array}$ & $\begin{array}{l}\text { Traditional } \\
\text { and fee-based }\end{array}$ & $\begin{array}{l}\text { Engagement } \\
\text { and fee-based }\end{array}$ & $\begin{array}{l}\text { Total } \\
\text { Events }\end{array}$ \\
\hline $\begin{array}{l}\text { Special } \\
\text { Events/year* }\end{array}$ & $16 \%$ & $44 \%$ & $0 \%$ & $39 \%$ & $645 /$ year \\
\hline $\begin{array}{l}\text { Regular } \\
\text { Events/month }\end{array}$ & $47 \%$ & $50 \%$ & $0 \%$ & $3 \%$ & $64 /$ month \\
\hline
\end{tabular}

* Due to rounding, not all categories add up to $100 \%$

Table 3: Tower Hamlets Special and Regular Library Events

\begin{tabular}{|l|l|l|}
\hline & Traditional (Free \& Fee-based) & $\begin{array}{l}\text { Engagement (Free \& Fee- } \\
\text { based) }\end{array}$ \\
\hline Special Events/year & $16 \%$ & $84 \%$ \\
\hline Regular Events/month & $47 \%$ & $53 \%$ \\
\hline Total Events/year & $33 \%$ & $67 \%$ \\
\hline
\end{tabular}

Table 4: Traditional vs. Engagement Events (Tower Hamlets) 
Perhaps the most notable feature is that for both services, 'engagement' events outnumber 'traditional', the proportions being quite similar.

One clear difference is the contrast between the numbers of special events offered by the two library services. Between April 2009 and March 2010, the Westminster libraries hosted 108 special events. By contrast, Tower Hamlets hosted 645 special events between September 2009 and August 2010. The inclusion of Idea Store Learning Courses in the count of special events held by the library during the period under review has contributed to the impressive number of special events offered by Tower Hamlets public libraries in a single year. However, even if the 288 Idea Store Learning Courses are removed from the equation, Tower Hamlets still offered 357 unique special events during the course of a single year, considerably exceeding Westminster's total. By definition, special events programming is more flexible and adaptable than regular and repeated events, and may enable the capturing of the attention of a wider spectrum of potential library visitors and users.

An apparent difference between the special events offerings of Westminster and Tower Hamlets relates to whether or not the library services charge for their special events. Only one of Westminster's 108 special events required attendees to pay an admission fee; this event, a live concert held in the library, was categorised as an engagement event. Of the 645 special events hosted by Tower Hamlets libraries in a single year, $39 \%$ charged a fee. Only one of these events - a writing workshop - was categorised as traditional event. The remainder of Tower Hamlets' fee-based events were Idea Store Learning Courses which have been categorised as engagement events; the equivalent in Westminster would be the responsibility of education services, instead of the library. A Tower Hamlets librarian noted that most of their library events were:

"free and should remain so [because Tower Hamlets is] committed to access and inclusion in a borough with high levels of poverty and illiteracy".

The difference here is therefore more apparent than real.

\subsection{Library services}

In order to gain an insight into the use of conventional library services in the two boroughs, data from the library statistics compiled by the Chartered Institute of Public Finance and Accountancy (CIPFA) were analysed. These give, for each London borough, a breakdown of active library members, library visits, book issues, and net service expenditure.

Since the latest available CIPFA data referred to the situation a year before the first programming data, a direct comparison was not possible. However, the data do show the general picture, as it has changed over time, from the initiation of CIPFA data in 1996. The full data and analysis may be found in Ship (2010).

The data show Westminster to have been the first- or second-ranked among inner London boroughs for book loans, library visits and library expenditure through the period from 1996, and top-ranked in the latest available figure.

Tower Hamlets, by contrast, has recorded a lower, and generally declining, rate of book loans and active borrowers; in the latest available figures, book loans were at 
their lowest point in the thirteen year period covered by the data, and the service ranked sixth among the boroughs. Visitor numbers, however, starting from a very low point, have increased steadily; in 2002, Tower Hamlets ranked last among the inner London borough, while in 2008, it was second only to Westminster.

Expenditure has similarly increased, from last place at the beginning of the period, to second place in 2008.

These data illustrate the profiles of the two services. Westminster has always resourced its libraries well, and has consistently maintained high-levels of use. Tower Hamlets, starting from a very low point in terms of resourcing and use, has seen increased resources rewarded by an increase in visits, but not - at least in the latest available data - by a corresponding increase in the traditional measures of public library use.

\subsection{Librarian viewpoint}

The views of staff of both services were sought, to better establish the context of the data collected, and to get the personal views of librarians on its significance. A set of questions was circulated to staff, and responses channelled via one individual, from whom further information and clarification was obtained. While by no means a formal survey of service providers, this gave valuable background information and perspectives.

In both cases, there was agreement that programmes and events were planned in support of the library's mission.

For Westminster, lacking a library mission statement, and also without any formal policy document on programming, this meant: "[supporting] reader development, learning and children's activities"; "[helping to] increase customer visits, promote reading and learning, and contribute to building the library's membership base"; "adding to the community activity in an area"; and "[making] our libraries more interesting and exciting places to visit".

These were seen as very much in line with the traditional role of the public library, and the idea of the library as 'leisure, learning and entertainment hub of the community' was complementary:

it is essential that libraries actively encourage their community to use the resources rather than to expect the numbers who simply borrow books to justify the expenditure.

For Tower Hamlets, library events and programmes contribute to objectives of the overall mission statement: learning, social cohesion, free access to information, and the provision of a safe and quality environment. However, as with Westminster, there is no policy document specifying how these are implemented in practice. It was taken to include:

[promoting] the services offered by the library, raising cultural awareness, supporting reader development, and responding to national initiatives.

Given that the idea was largely pioneered in Tower Hamlets, it is not surprising that there was agreement about the 'community hub' status for the public library: "this is the way forward". However, there was recognition that this must be 
thoughtfully implemented, in order to avoid alienating some of the library's customer base. Not all patrons look for the same atmosphere, and many Tower Hamlet's users regret the loss of the traditional library 'quiet space'.

The main weaknesses in Westminster's provisions were perceived as due to a limited events budget, and a shortage of suitable spaces; only two library branches have an events room. Tower Hamlets, with its Idea Store buildings designed with events in mind, is better off in this respect. Perceived weaknesses in provision there were that "the events have not always been related to core activities, nor have [they] always been signposting to another activity/service". In their recent report, there is the acknowledgement that integration of learning and library services has not been as seamless as intended, and this aspect should be improved (Tower Hamlets, 2009).

The Westminster librarians noted that their engagement programming was generally better supported than more traditional library events, with learning events particularly appreciated. Although Westminster's library staff make a point of promoting library materials whenever possible during events, Westminster has no formal mechanism for determining whether events stimulate book borrowing, and other use of library materials.

At Tower Hamlets, the success in attracting large numbers of attendees, particularly to engagement events is clear, but the comment was made that both engagement and traditional programming serve patron needs in different ways, and both should be continued. The importance of continually reviewing, evaluating and revising programming was emphasised, although a weakness was noted in that the service "have not made clear what our objectives have been in organising an event and have not therefore measured outcomes". A link between events and the loan of library materials is difficult to prove in most cases, although a librarian confidently asserted that events such as Summer Reading Challenge for children encourage major increases in book issues.

Future prospects for programming at Westminster are clearly dependent on financial issues; staff envisage them continuing at the same level, with a likelihood that more learning events will be arranged. For Tower Hamlets, funding is similarly the determining issue. There is currently a process of developing more book-based activities, with a particular effort to ensure that "all children's activities [will be focused] around books and reading", and generally to increase "focus on core services of reader development and information". Immediate action on this includes an increase in the number of book groups, and the planning of a literary festival.

These latter responses seem to show a striking degree of convergence between the services, as Westminster seeks to arrange more activities categorised as innovative engagement, while Tower Hamlets moves back towards more traditional core library concerns.

\section{Discussion}

Given the limitations of this study, acknowledged above, its conclusions must be tentative. There can be no attempt to conclude that one model of service is 'best', 
even if such a judgement were meaningful, still less any recommendation for all to adopt: as Murison (1988, ix) reminds us:

only when a particular library area's nature and needs have been thoroughly surveyed can a plan of priorities... be drawn up for its community.

(Murison, 1988, ix)

Indeed, one important lesson emerges in these limitations. The inconsistent and incomplete record keeping which made this study less rigorous than might have been, must also affect internal service evaluation and inter-service comparison. Standardised data sets are essential if such performance analyses, which are increasingly regarded as vital, are to be of maximum value.

The desirability of clear mission statements or similar documents, as advocated by commentators such as McMenemy (2009) appears undeniable, particularly in justifying the integration of, for example, library and learning services. Yet in both these services - one with a definite overall mission statement and one without - there was a lack of policy directive at the operational level. Mission statements and the like are only worthwhile if they 'trickle down' into practical policies on the ground.

Westminster, operating a traditional service model, has consistently performed better than Tower Hamlets by the usual measures of library service, although its visitor numbers have declined over the years; while the investment in the Idea Store rebranding has greatly increased use in the sense of visitor numbers in Tower Hamlets, it has not as yet greatly increased take-up for core library services. Whether the increased financial resources might have had a similar effect if used on a more conventional service, it is impossible to say. Indeed, the proper measure of service effectiveness, and how book borrowing is to be weighed against attendance at library events, is a vexed question, calling to mind the long-standing debate about the leisure role of public libraries (Snape 1995, Black 1996, Usherwood 2007). The controversy continues more recently, with Leadbeater (2003) being an example of those advocating the primacy of general and cultural usage, whilst Coates (2004) might be seen as an example of those favouring a focus on books. The results of this study might, perhaps, suggest that this is an empty argument; the answer is surely 'both'.

Now that its libraries have successfully implemented an engagement service model - although, as noted above, one which has antecedents in UK public library history - Tower Hamlets views core library services as the next growth area for boosting the use of its public library and lifelong learning services. The message to be found here is that while an engagement service model does work to capture the imagination of potential library users and to encourage wider use of library and lifelong learning services, the core offer of services which set libraries apart from other institutions, must always be of high quality.

\section{Conclusion}

Despite the numerous media comments for and against the Idea Store model, this study is one of the few critical analyses and comparisons of such services so far reported. Radical redevelopment of public library services along Tower Hamlets' 
lines may not be possible, desirable or necessary, for all public libraries. It seems that it may be, however, particularly in its integration of library and learning services, and in its provision of special programming, a constructive point of departure for other authorities seeking to revitalise their public library provision, particularly if increasing usage is the first priority.

\section{References}

Begg, R. (2009) Death or diversification: The use of space in public library buildings. Aslib Proceedings, 61(6), 619-635.

Black, A. (1996) A new history of the English public library: social and intellectual contexts, 1850-1914. Leicester: Leicester University Press.

Cassell, K.A and Weibel, K. (2007) Public library response to women and their changing roles revisited. Library Trends, 56(2), 303-327.

Clarke, M. (2007) At the hub? Public Library Journal, 22(1), 27-28.

Coates, T. (2004) Who's in charge?: Responsibility for the public library service. London: Libri Trust.

DCMS (2010) A modernisation review of public libraries: a policy statement. London: Department of Culture, Media and Sport.

GLA (2011) London Borough Profiles. London: Greater London Authority Intelligence Unit [Online]. URL:

http://data.london.gov.uk/datastore/package/london-borough-profiles [accessed 13.06.12].

Hood, D. and Henderson, K. (2005) Branding in the United Kingdom public library service. New Library World, 106(1/2), 16-28.

Joliffe, H. (1968) Public library extension activities. $2^{\text {nd }}$ Ed. London: Library Association.

Kelly, T. (1973) A history of public libraries in Great Britain, 1845-1965.

London: Library Association.

Koontz, C. and Gubbin, B. (2010) IFLA Public Library Service Guidelines. $2^{\text {nd }}$ Ed. IFLA Publications No. 147, Berlin: De Gruyter Saur.

Leadbeater, C. (2003) Overdue: how to create a modern public library service. London: Demos [Online]. URL: http://www.demos.co.uk/publications/overdue [accessed 31.10.12].

Leyland, E. (1938) The wider public library. London: Grafton.

McMenemy, D. (2000) Public libraries and social exclusion: the historical legacy. Working Paper No. 2 [Online]. URL: http://eprints.rclis.org/bitstream/10760/7119/1/vol3wp2.pdf [accessed 31.10.12].

McMenemy, D. (2009) The public library. London: Facet.

Murison, W.J. (1988) The public library: its origins, purpose and significance. $3^{\text {rd }}$ Ed. London: Bingley. 
Pateman, J. and Vincent, J. (2010) Public libraries and social justice. Farnham: Ashgate.

Pitman, K. (2012) A roaring trade in ideas. CILIP Update, June 2012, 32-35.

Ship, M. (2010) What's on at Tower Hamlets and Westminster Libraries?: a study of the Idea Store service model vs. the traditional public library service model. [Unpublished MSc dissertation]. London: City University London.

Snape, R. (1995) Leisure and the rise of the public library. London: Library Association.

Sydney, E. (1950) United Kingdom, In: Thomsen, C., Sydney, E. and Tomkins, M.D. (eds.) Adult Education Activities for Public Libraries. Paris: UNESCO, pp. 21-53.

Tower Hamlets (1999) A Library and Lifelong Learning Development Strategy for Tower Hamlets, London: Customer Services and Education Directorates for the Arts, Leisure, Sports and Youth and Community Services Committees, Tower Hamlets Borough Council. [Online]. URL:

http://www.ideastore.co.uk/public/documents/PDF/A_Library_and_Lifelong_Lea rning_Development_Strategy_for_Tower_Hamlets.pdf [accessed 31.10.12].

Tower Hamlets (2009) Idea Store Strategy 2009. London: Tower Hamlets Borough Council [Online]. URL:

http://www.ideastore.co.uk/public/documents/PDF/IdeaStoreStrategyAppx1CAB 290709.pdf [accessed 31.10.12].

Usherwood, B. (2007) Equity and excellence in the public library: Why ignorance is not our heritage. Farnham: Ashgate.

Varheim, A. (2011) Gracious space: library programming strategies towards immigrants as tools in the creation of social capital. Library and Information Science Research, 33(1), 12-18.

Whatley, H. (ed.) British librarianship and information science, 1966-1970. London: Library Association.

Wills, H. (2003) An innovative approach to reaching the non-learning public: the new Idea Stores in London. New Review of Libraries and Lifelong Learning, 4, 107-120.

\section{Open access and copyright}

Library and Information Research is an open access journal. A freely available copy of this paper may be downloaded from the journal's website:

http://www.cilipjournals.org.uk/lir

Copyright and associated moral rights in works published in Library and Information Research are retained by the author(s) but this paper may be used freely, with proper attribution, in educational and other non-commercial settings. 